\title{
Priming of Stylosanthes seeds
}

\author{
Condicionamento osmótico de sementes de Stylosanthes
}

\author{
Karina Margareti de Castilio Alencar ${ }^{I}$ Adriana Paula D’Agostini Contreiras Rodrigues ${ }^{I I}$ \\ Silvia Rahe Pereira ${ }^{\text {III }}$ Valdemir Antônio Laura ${ }^{\text {I, II, IV }}$
}

\begin{abstract}
It is estimated that $60 \%$ of the area of cultivated pasture, in the Brazilian Savannah, is degraded or in process of degradation, due to, among other causes, the lack of nitrogen. The Stylosanthes genus is the legume which has the greater number of cultivars used in tropical pastures, however, its seeds have characteristics which can difficult the formation of an adequate stand of plants on pasture. In this research the aim was to evaluate the effects of priming in the speed and uniformity of the Stylosanthes capitata, S. macrocephala and S. guianensis seeds germination. The seeds were kept for 12, 24, 36 and 48 hours in aired media PEG 6,000 at 0.0, -0.5, 1.0 and $-1.5 \mathrm{MPa}$. Afterwards, they were sent to the germination test. The variables analyzed were germination percent, germination speed index (GSI) and average germination time (AGT). For S. capitata it is recommended priming at $0.0 \mathrm{MPa}$ for 10 hours, and for $\boldsymbol{S}$. macrocephala the recommended potential is -0.5 MPa. However, for the $\boldsymbol{S}$. guianensis the priming is not recommended under the time and potentials evaluated in this research.
\end{abstract}

Key words: forage, physiological quality, legume, priming.

\section{RESUMO}

Atualmente, estima-se que $60 \%$ da área de pastagem cultivada, no Cerrado, esteja degradada ou em processo de degradação, devido, entre outras causas, à deficiência de nitrogênio. O gênero Stylosanthes é uma leguminosa que possui maior número de cultivares usadas em pastagens tropicais, no entanto, suas sementes apresentam características que podem dificultar a formação de um estande adequado da pastagem. O objetivo deste trabalho foi avaliar os efeitos do condicionamento osmótico na velocidade e uniformidade da germinação das sementes de Stylosanthes capitata, S. macrocephala e S. guianensis. As sementes foram mantidas por um período de 12, 24, 36 e 48 horas em solução aerada de PEG 6000 a 0,0, -0,5, -1,0 e -1,5MPa, sendo posteriormente submetidas ao teste de germinação. Foram avaliadas as variáveis porcentagem de germinação, índice de velocidade de germinação (IVG) e tempo médio de germinação (TMG). Para S. capitata, recomenda-se o condicionamento a $0,0 \mathrm{MPa}$ durante 10 horas e para S. macrocephala o potencial recomendado é de -0,5MPa. No entanto, para S. guianensis, o condicionamento não é recomendado sob os potenciais $e$ períodos testados neste trabalho.

Palavras-chave: forrageira, qualidade fisiológica, leguminosa, osmocondicionamento.

\section{INTRODUCTION}

It is currently estimated that $60 \%$ of Brazilian cultivated pasture are degraded or in process of degradation, due to, among others, the lack of nitrogen (SOUSA et al., 2004). As the area to be restored is too vast, it makes impossible the use of nitrified

'Programa de Pós-graduação em Biologia Vegetal, Universidade Federal de Mato Grosso do Sul (UFMS), Campo Grande, MS, Brasil. "Programa de Pós-graduação em Produção e Gestão Agroindustrial, Universidade Anhanguera-Uniderp, Campo Grande, MS, Brasil. "IIIrograma de Pós-graduação em Ecologia e Recursos Naturais, Universidade Federal de São Carlos (UFSCAR), São Carlos, SP, Brasil.

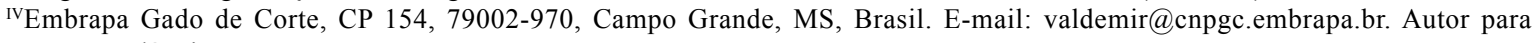
correspondência. 
compounds, considering the overall cost of it. A possible solution for the question has been the use of legume species that, due to their capacity to retain nitrogen from the air, maintain higher levels of protein than grass, what is of great importance to the bovine exploratory system of Brazil. The genus Stylosanthes is the one in greater quantity among the tropical leguminous utilized in pasture (KARIA et al., 2002). Nevertheless, an important characteristic that should be taken into consideration when choosing the specie of forage is the strength of its seeds, which is a fundamental factor for the quick and uniform establishment of plants in the fields.

A great variety of techniques have been proposed to reduce the necessary time between sowing and seedling emergence, being that among them, there is the priming. This treatment means soaking the seeds in osmotic medium for a certain period of time and after it, drying them back to their original state (NASCIMENTO, 1998), which facilitates handling and/ or storing. Moreover, this treatment is a viable alternative to favor an increase in the performance of seeds in the field, particularly under adverse conditions and in lots with low vigor (McDONALD, 1998).

Despite being relatively simple, the technique of priming has many factors that can influence its success, between them, the type of osmotic medium, the osmotic potential, the temperature, the length of soaking, air, light, washing and drying (NASCIMENTO, 1998). In this way, the present research aimed to establish methodologies of priming for S. capitata, S. macrocephala and S. guianensis seed species, evaluating the effects in the germination percentage, uniformity and speed.

\section{MATERIAL AND METHODS}

The experiments were carried out from September to December 2007 at EMBRAPA Beef Cattle in Campo Grande - MS - Brazil, with three seed species of the Stylosanthes genus (S. macrocephala M. B. Ferreira \& S. Costae, S. capitata Vogel and S.guianensis (Aubl.) Sw.), obtained in July 2007.

The priming tests were done in order to select the best treatment, with the direct immersion method of the seeds in water solution with potential: 0.0 (distilled water), $-0.5 ;-1.0$ and $-1.5 \mathrm{MPa}$, obtained with PEG 6,000 solution (polyethylene glycol 6,000), according to VILLELA et al. (1991), under constant aeration. There were placed $3.0 \mathrm{~g}$ of seeds of each species in $250 \mathrm{~mL}$ plastic pots with $100 \mathrm{~mL}$ of PEG 6,000 solution, in the specific concentration to each treatment, in a chamber with constant temperature $\left(25^{\circ} \mathrm{C}\right)$, with photoperiod of $12 \mathrm{~h}$. The priming was tested in the periods of 12, 24, 36 and 48 hours and compared with unprimed seeds, being that, after the respective priming periods, the seeds were washed in running water for two minutes (NASCIMENTO \& ARAGÃO, 2004), and put to dry in gerbox with germitest paper in room ambient temperature $\left(24-27^{\circ} \mathrm{C}\right)$ for 48 hours (EIRA \& MARCOS-FILHO, 1990). After dried, the seeds were put in paper bags at room temperature, in the laboratory, and the germination tests were performed. Seed moisture content before and after each treatment was determined by the kiln at $105^{\circ} \mathrm{C}$ method (BRASIL, 2009).

After the drying the seeds were set for germination, including unprimed seeds, in four repetitions of 100 per treatment, on germitest paper and moistened with the equivalence of 2.5 times the substrate of distilled water. The seeds were then incubated in germination chamber Biochemical Oxigen Demand (BOD) with photoperiod of 12 hours and alternated temperatures of $20-30^{\circ} \mathrm{C}$ for 10 days, according to the Seed Analysis Rules (BRASIL, 2009). Evaluations were done daily, considering as germinated seeds the ones which presented at least $2.0 \mathrm{~mm}$ of primary root.

The effects of the treatment in the physiological quality of the seed were evaluated by germination test, germination speed Index (GSI) and average germination time (AGT), being the GSI calculated accordingly to KRZYZANOWSKI (1999). An analysis of variance and polynomial regression was performed, with the significance tested through the test $\mathrm{F}$, with up to $5 \%$ of probability and the data, when necessary, was transformed.

\section{RESULTS AND DISCUSSION}

Seed moisture content before priming was about $7.9 \%$; just after $50 \%$ and after four days at room temperature for drying was $8.9 \%$, close to the initial moisture content (Table 1).

In the $S$. capitata, the potential of $-0.5,-1.0$ and $-1.5 \mathrm{MPa}$ in the many stages of the priming did not have significant effect in the germination percentage (Figure 1A) which implies that, in spite of not having promoted any improvement, it did not result into germination loss. The stage of priming in distilled water (potential 0.0MPa) however, showed significant effect in the percentage of $\boldsymbol{S}$. capitata seeds germination (Figure 1A). In other words, the germination maximum would be obtained after 9.1 hours of priming in distilled water, which has shown a germination increasing of $16.8 \%$ in comparing to unprimed seeds (67.7 and $57.9 \%$ of germinations, respectively). 
Priming of Stylosanthes seeds.

Table 1 - Stylosanthes capitata, S. macrocephala and S. guianensis seeds moisture content (\%) after different periods (hours) of priming and after four days at room temperature and to unprimed seeds.

\begin{tabular}{|c|c|c|c|c|c|c|c|c|c|c|c|c|}
\hline \multicolumn{13}{|c|}{ Seed moisture content (\%) after different periods of time (hours) } \\
\hline \multirow[b]{2}{*}{$\mathrm{OP} *$} & \multicolumn{4}{|c|}{----------------S. capitata----------------- } & \multicolumn{4}{|c|}{-----------S. macrocephala------------ } & \multicolumn{4}{|c|}{--------------S. guianensis------------- } \\
\hline & $12 \mathrm{~h}$ & $24 \mathrm{~h}$ & $36 \mathrm{~h}$ & $48 \mathrm{~h}$ & $12 \mathrm{~h}$ & $24 \mathrm{~h}$ & $36 \mathrm{~h}$ & $48 \mathrm{~h}$ & $12 \mathrm{~h}$ & $24 \mathrm{~h}$ & $36 \mathrm{~h}$ & $48 \mathrm{~h}$ \\
\hline 0 & 51.6 & 53.2 & 53.6 & 55.1 & 54.3 & 55.6 & 57.7 & 56.9 & 44.5 & 47.8 & 51.1 & 50.9 \\
\hline-0.5 & 49.4 & 43.0 & 50.7 & 48.9 & 51.3 & 51.7 & 52.6 & 52.0 & 36.6 & 39.5 & 35.3 & 45.1 \\
\hline-1.0 & 49.1 & 58.2 & 48.4 & 51.0 & 49.7 & 50.7 & 53.3 & 50.9 & 35.3 & 42.2 & 49.3 & 45.2 \\
\hline-1.5 & 48.5 & 50.1 & 48.9 & 49.1 & 49.6 & 51.5 & 51.8 & 51.2 & 35.5 & 39.0 & 38.6 & 44.1 \\
\hline \multicolumn{13}{|c|}{ Seed moisture content (\%) after four days at room temperature } \\
\hline & \multicolumn{4}{|c|}{ 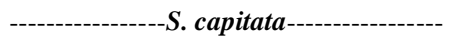 } & \multicolumn{4}{|c|}{ 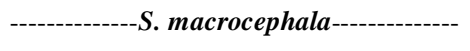 } & \multicolumn{4}{|c|}{ 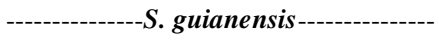 } \\
\hline OP* & $12 \mathrm{~h}$ & $24 \mathrm{~h}$ & $36 \mathrm{~h}$ & $48 \mathrm{~h}$ & $12 \mathrm{~h}$ & $24 \mathrm{~h}$ & $36 \mathrm{~h}$ & $48 \mathrm{~h}$ & $12 \mathrm{~h}$ & $24 \mathrm{~h}$ & $36 \mathrm{~h}$ & $48 \mathrm{~h}$ \\
\hline 0 & 9.9 & 9.7 & 10.2 & 9.8 & 9.7 & 10.4 & 8.3 & 9.4 & 8.2 & 7.8 & 9.7 & 7.5 \\
\hline-0.5 & 9.6 & 9.9 & 9.8 & 9.8 & 9.6 & 10.0 & 8.1 & 9.7 & 7.8 & 7.4 & 8.6 & 7.5 \\
\hline-1.0 & 9.3 & 9.8 & 10.0 & 9.8 & 9.5 & 10.0 & 8.3 & 9.5 & 7.6 & 8.0 & 8.3 & 7.2 \\
\hline-1.5 & 9.2 & 9.7 & 9.9 & 9.9 & 9.7 & 9.7 & 8.1 & 9.6 & 7.6 & 7.0 & 8.3 & 7.3 \\
\hline \multicolumn{13}{|c|}{ Seed moisture content (\%) to unprimed seeds } \\
\hline \multicolumn{5}{|c|}{ Stylosanthes capitata } & \multicolumn{4}{|c|}{8.4} & & & & \\
\hline \multicolumn{5}{|c|}{ Stylosanthes macrocephala } & \multicolumn{4}{|c|}{7.5} & & & & \\
\hline \multicolumn{5}{|c|}{ Stylosanthes guianensis } & & 7.9 & & & & & & \\
\hline
\end{tabular}

$* \mathrm{OP}=$ Osmotic potential $(\mathrm{MPa})$.

This results are in accordance to the ones obtained by POSSE et al. (2002) who while working with green pepper seeds (Capsicum annuum L.), observed that these seeds showed higher germination percentage when primed at $25^{\circ} \mathrm{C}$ in distilled water (0,0MPa) and in PEG 6,000 solution (-1.0MPa). However, BRACCINI et al. (1999) when primed soybean seeds (Glycine max (L.) Merr.) in PEG 6,000 (-0.8MPa), at $20^{\circ} \mathrm{C}$, did not observed significant differences between primed and unprimed seeds, however, the primed seeds in demineralized water showed worse results, slowing the protrusion of the primary root.

Regarding the GSI (germination speed index) through regression analysis, it was observed that only seeds primed in the osmotic potential $(\Psi \mathrm{s})$ of $-1.5 \mathrm{MPa}$ presented positive linear effect, that means, the increase in the time of priming also increased the GSI (Figure 1B). In the other $\Psi \mathrm{s}$ the data adjusted to third degree equation, within $10.2 ; 9.8$ and 15.1 hours, for $\Psi \mathrm{s}$ $0.0 ;-0.5$ and $-1.0 \mathrm{MPa}$, with GSI of 39.4, 34.9 and 52.4, respectively. In general, the most elevated GSI's were obtained with priming under $\Psi \mathrm{s}-1.0 \mathrm{MPa}$ for a period of 15 hours (52.4) and $-1.5 \mathrm{MPa}$ for a 48 hours period (48.1), higher in 90.5 and $74.9 \%$ when comparing to unprimed seeds (27.5). The most expressive results, to either GSI and AGT (Figure 1C), were seen when seeds were primed under $\Psi$ s of $-1.0 \mathrm{MPa}$ for 15 and 24.7 hours, respectively, which corresponded to $90.5 \%$ of increase in the GSI with AGT of 2.4 days, while to unprimed seeds the AGT was 4.2 days.

Under the $\Psi \mathrm{s}$ of $-1.5 \mathrm{MPa}$ the seeds presented the best AGT results, though very close to the numbers obtained under $\Psi_{\mathrm{S}}-1.0 \mathrm{MPa}$. These results have already been observed in researches, such as BONOME et al. (2006) who observed that, when priming the Brachiaria brizantha (Hochst. ex A. Rich.) Stapf. cv. Marandu seeds in $\Psi$ s of $-0.9 ;-1.1$ and $-1.4 \mathrm{MPa}$, the decreasing in the osmotic potential of the solution tended to increase the germination speed index. However, as the reduction in the osmotic potential of the used solution didn't result in an increase in the germination percentage, it is recommended, for this species, the priming of the seeds under $\Psi_{\mathrm{s}} 0.0 \mathrm{MPa}$ during 10 hours because, in this condition, it was also obtained a small increase in GSI.

In the $\boldsymbol{S}$. macrocephala, the periods of priming under $\Psi$ s of -1.0 and $-0.5 \mathrm{MPa}$ did not show significant change in the percentage of germination, as it can be seen in the regression analysis represented in figure $2 \mathrm{~A}$. Under $\Psi_{\mathrm{s}}=-1.5 \mathrm{MPa}$ the effect during the soaking process was negative, except when it was extended to 45 hours. As well as in the case of the $\boldsymbol{S}$. capitata (Figure 1A), the seeds when primed in distilled water $(0.0 \mathrm{MPa})$ showed higher germination percentage (70.2\%) with maximum in 24.2 hours, superior from the ones unprimed $(61.5 \%)$ in $14.1 \%$. 

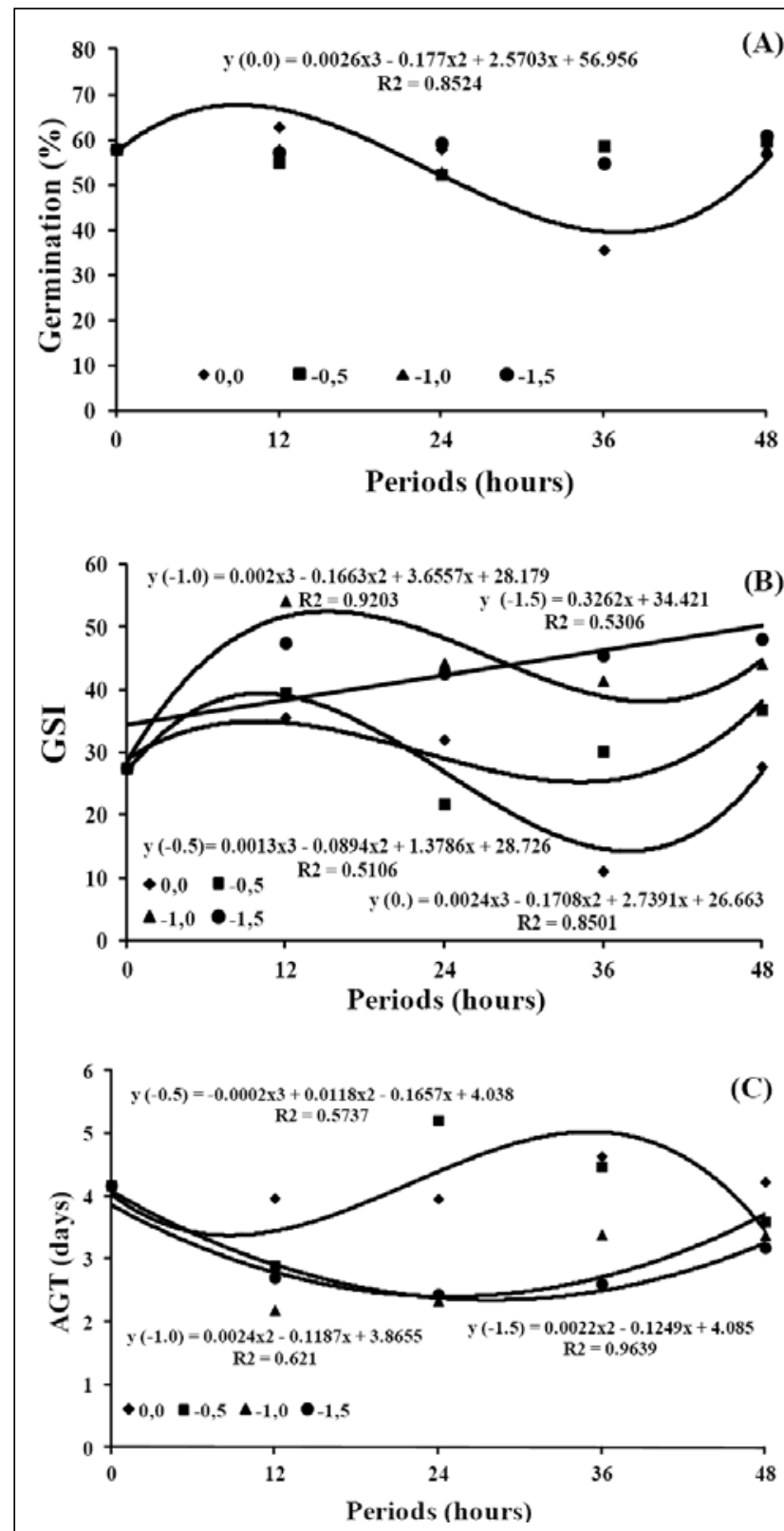

Figure 1 - Germination Percentage (A), Germination Speed Index (GSI) (B) and Average Germination Time (AGT) (C) of S. capitata seeds primed under different osmotic potentials and for different periods.

In the GSI of S. macrocephala (Figure 2B), all priming periods in all $\mathrm{s}$ tested were potentially greater than the unprimed seeds, except for the $\mathrm{s}$ of $1.5 \mathrm{MPa}$ up to 18.7 hours as observed in figure $2 \mathrm{~B}$. The most expressive results were under $\mathrm{s}-0.5 \mathrm{MPa}$ at 19.3hours (74.4) and under $\Psi_{\mathrm{S}}-1.0 \mathrm{MPa}$ at 48 hours (73.5) with 101.6 and $99.2 \%$, respectively, of superiority when compared to unprimed seeds (36.9). The binominal of $\Psi_{\mathrm{S}}$ and priming time also influenced the germination speed, being the best (lowest) results obtained under priming of $\Psi \mathrm{s}-1.0$ and $-1.5 \mathrm{MPa}$ for 48 hours (Figure $2 \mathrm{C}$ ).

Considering the germination percentage, S. macrocephala and $\boldsymbol{S}$. capitata showed lighter increment when their seeds were primed in distilled water $(0.0 \mathrm{MPa})$ which is in accordance to MENDONÇA et al. (2005), who affirmed that there are evidences that water priming, at certain temperature, during a specific period of time, according to the species, is favorable to the germination percentage and increase the seeds germination speed and vigor. The extremely negative hydro potentials, especially in the beginning of the soaking, influence the water absorption and can make not viable the sequence of events which culminate with the emergence of seedlings (BERTAGNOLLI et al., 2003), retarding or reducing the germination speed in many vegetation species, due to the interference in the seeds hydration (TAMBELINI \& PEREZ, 1998).

However, it's not possible to prescribe the treatment under $\Psi$ s of $0.0 \mathrm{MPa}$ for both species, considering that during the priming of $\boldsymbol{S}$. macrocephala it was observed the protrusion of roots in most of the seeds, in all periods of priming. In accordance to the data obtained by TRIGO et al. (1999) when primed onion seeds (Allium cepa L.) in water it was observed increments in the seeds germination percentage and speed. Nevertheless, it was also observed at 24 hours of soaking in water the protrusion of seminal roots, which would make it not recommendable in the adopted time.

For S. macrocephala with $\Psi$ s of $0.5 \mathrm{MPa}$ the germination under priming did not occur only at 12 hours, indicating the necessity of shorter periods to repair the membrane, knowing that during the priming, the seeds will go through all physiological processes, without reaching the protrusion of the primary or seminal roots. In this potential, in spite of the germination percentage wasn't affected, the treatment of the seeds for 19.3hours resulted in increase of GSI and reduction of AGT (Figure 2A, B, C). Therefore, for this species the recommended potential is $-0.5 \mathrm{MPa}$.

In the $\boldsymbol{S}$. guianensis, all tested treatments (osmotic potential and priming periods) have shown decrease in the germination percentage and GSI (Figures 3A, B). Regarding the AGT there was no benefit of priming, as it can be seen in figure $1 \mathrm{C}$. Similar results 


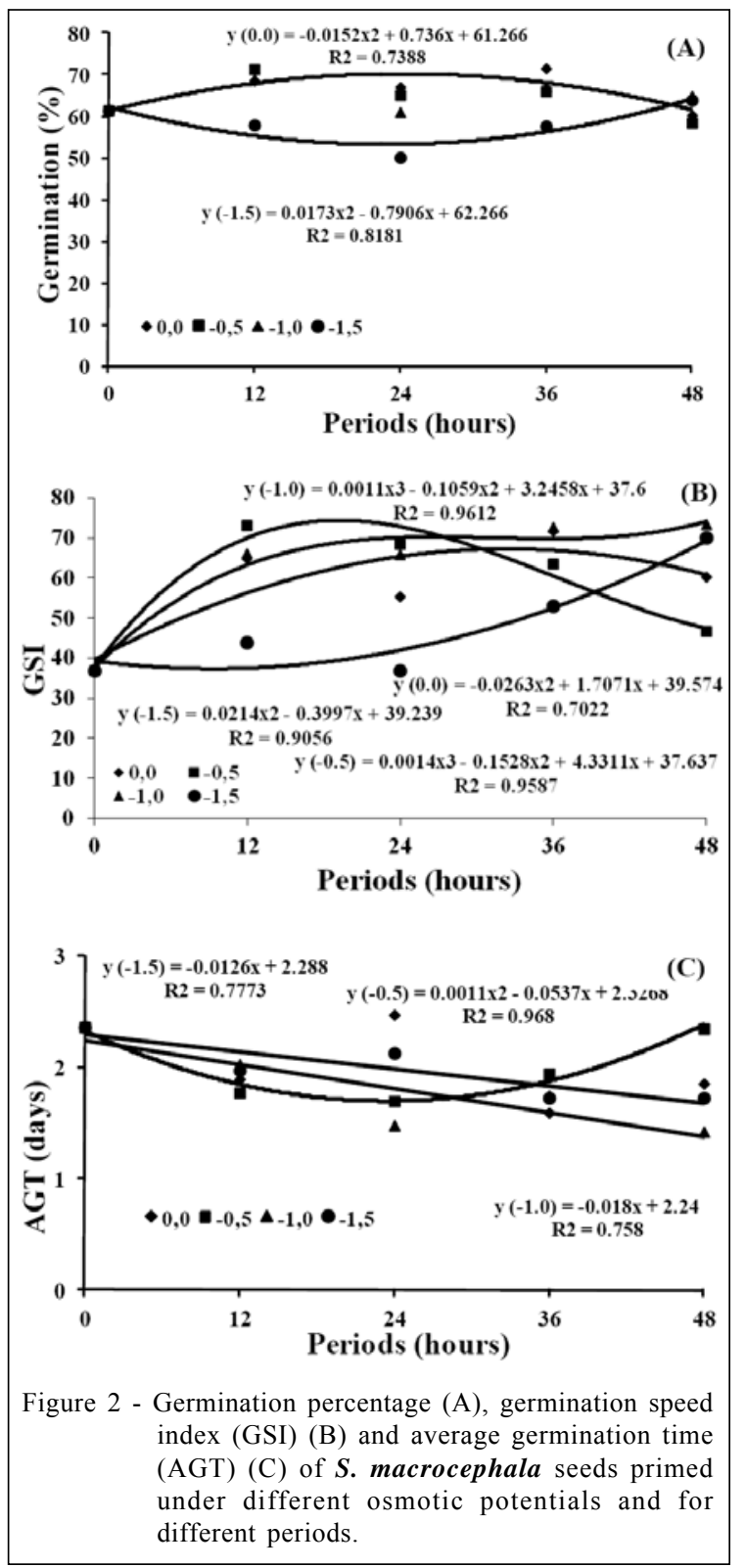

were obtained by FONSECA \& PEREZ (2003) when testing Adenanthera pavonina $\mathrm{L}$. seeds under different osmotic potentials, combined with polyamines and different temperatures, having in this case, the unprimed ones presented better performance than the others. In experiments of priming with sorghum seeds, CARVALHO et al. (2000) observed that the priming in PEG 6,000 did not show any difference between the primed and unprimed seeds.

Based on this data, for S. guianesis, together with the already presented for $\boldsymbol{S}$. capitata and $\boldsymbol{S}$.

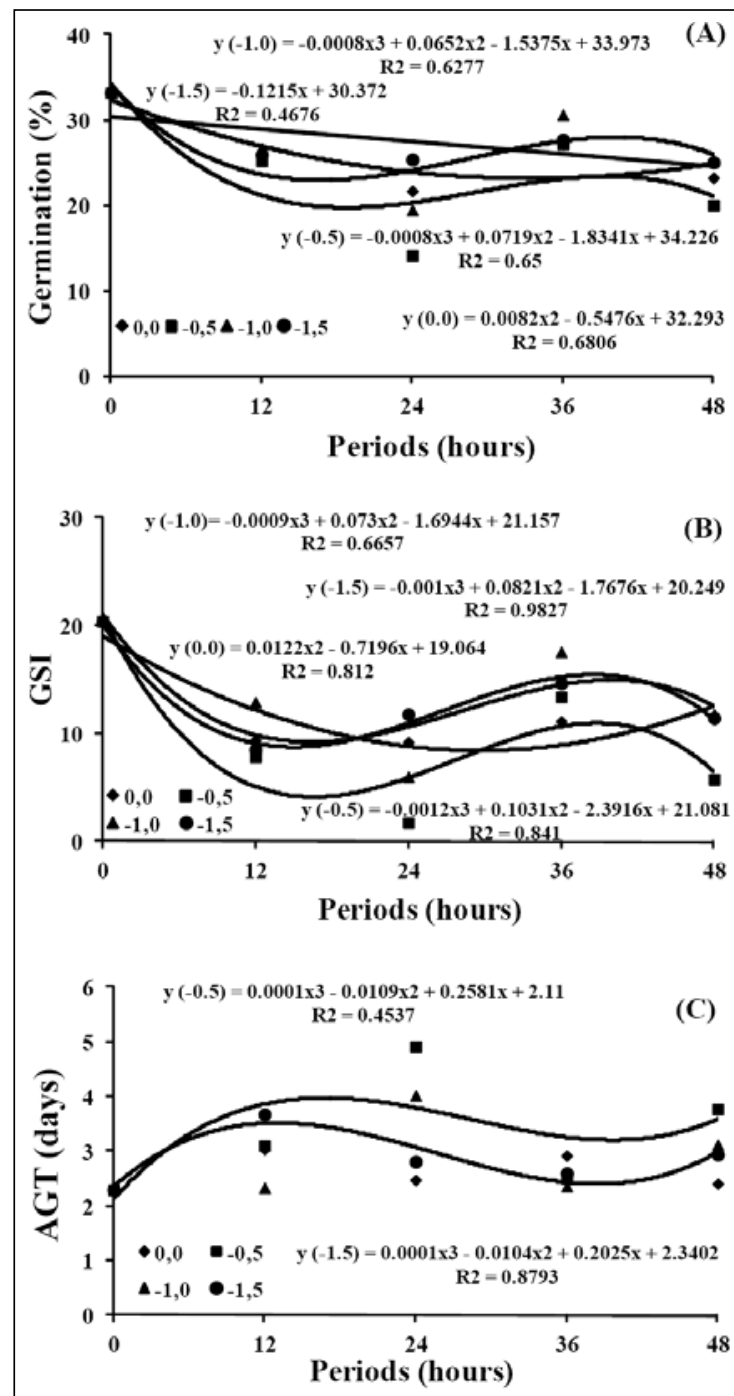

Figure 3 - Germination Percentage (A), Germination Speed Index (GSI) (B) and Average Germination Time (AGT) (C) of $\boldsymbol{S}$. guianensis seeds primed under different osmotic potentials and for different periods of time.

macrocephala, it is possible to observe that though the priming did not have any significant effect on seeds, regarding germination percentage, it did not result in the loss of these seeds germination potential. This fact can be explained by observing EIRA (1988) which, in non published data, quotes that the priming increases the germination percentage or leave it unchanged for high quality seeds. NASCIMENTO (1998) also affirmed that the efficiency of priming depends, among other factors, of the initial quality of the seed, knowing that seeds of high physiological quality, do not respond to priming. 


\section{CONCLUSION}

It is recommended for the $\boldsymbol{S}$. capitata the priming under s $0.0 \mathrm{MPa}$ during 10 hours and for the S. macrocephala the priming under $\mathrm{s}-0.5 \mathrm{MPa}$. In the case of $\boldsymbol{S}$. guianensis, the priming is not recommended under the time and potentials evaluated in this research.

\section{ACKNOWLEDGEMENTS}

To the Foundation for the Development of Teaching, Science and Technology of Mato Grosso do Sul (FUNDECT/MS) for granting a Master's Degree scholarship to the first author and for financing the research project $41 /$ $100.136 / 05$ (Technology for the increasing of productivity and quality in tropical forage seeds).

\section{REFERENCES}

BERTAGNOLLI, C.M. et al. Desempenho de sementes nuas e peletizadas de alface (Lactuca sativa) submetidas aos estresses hídrico e térmico. Revista Brasileira de Sementes, v.25, n.1, p.7-13, 2003. Available from: <http:/www.scielo.br/pdf/ rbs/v25n1/19623.pdf>. Accessed: Sept. 09, 2010. doi: 10.1590/ S0101-31222003000100002.

BONOME, L.T.S. et al. Efeito do condicionamento osmótico em sementes de Brachiaria brizantha cv. 'Marandu'. Ciência e Agrotecnologia, v.30, n.3, p.422-428, 2006. Available from: $<$ http://www.scielo.br/pdf/cagro/v30n3/v30n3a06.pdf $>$. Accessed: Sept. 09, 2010.

BRACCINI, A.L. et al. Avaliação da qualidade fisiológica de sementes de soja após o processo de hidratação-desidratação e envelhecimento acelerado. Pesquisa Agropecuária Brasileira, v.34, n.6, p.1053-1066, 1999. Available from: $<$ http://www.scielo.br/pdf/pab/v34n6/8408.pdf $>$. Accessed: Sept. 09, 2010. doi: 10.1590/S0100-204X1999000600018.

BRASIL. Regras para análise de sementes. Brasília: SNDA/ DNDV/CLAV, 2009. 395p.

CARVALHO, L.F. et al. Condicionamento osmótico de sementes de sorgo. Revista Brasileira de Sementes, v.22, n.1, p.185192, 2000. Available from: <http://www.abrates.org.br/revista/ artigos/2000/v22n1/artigo25.pdf >. Accessed: Sept. 09, 2010.

EIRA, M.T. Condicionamento osmótico de alface: efeitos sobre a germinação e desempenho sob estresse hídrico, salino e térmico. 1988. 90f. Dissertação (Mestrado em Fitotecnia) Escola Superior de Agricultura 'Luiz de Queiroz', Universidade de São Paulo, SP.

EIRA, M.T.S.; MARCOS-FILHO, J. Condicionamento osmótico de sementes de alface. II. Desempenho sob estresses hídrico, salino e térmico. Revista Brasileira de Sementes, v.12, n.1, p.28-45, 1990. Available from: <http://www.abrates.org.br/ revista/artigos/1990/v12n1/artigo02.pdf >. Accessed: Sept. 09, 2010 .

FONSECA, S.C.L.; PEREZ, S.C.J.G.A. Ação do polietileno glicol na germinação de sementes de Adenanthera pavonina L. e o uso de poliaminas na atenuação do estresse hídrico sob diferentes temperaturas. Revista Brasileira de Sementes, v.25, n.1, p.1-6, 2003. Available from: <http://www.scielo.br/ $\mathrm{pdf} / \mathrm{rbs} / \mathrm{v} 25 \mathrm{n} 1 / 19622 . \mathrm{pdf}>$. Accessed: Sept. 09, 2010. doi: 10.1590/S0101-31222003000100001.

KARIA, T.C. et al. Caracterização morfológica de acessos do gênero Stylosanthes no banco ativo de germoplasma da Embrapa Cerrados - Coleção 1994/1995. Boletim de desenvolvimento de pesquisa, v.72, $24 \mathrm{p}, 2002$. Available from: www.cpac.embrapa.br/download/81/t. Accessed: Sept. 09, 2010.

KRZYZANOWSKI, F.C. et al. Vigor de sementes: conceitos e testes. Londrina: Abrates, 1999. 21p.

McDONALD, M.B. Seed quality assessment. Seed Science Research, v.8, n.2, p.265-275, 1998.

MENDONÇA, A.V.R. et al. Efeito da hidratação e do condicionamento osmótico em sementes de pau-formiga. Revista Brasileira de Sementes, v.27, n2, p.111-116, 2005. Available from: <http://www.scielo.br/pdf/rbs/v27n2/ a16v27n2.pdf>. Accessed: Sept. 09, 2010. doi: 10.1590/S010131222005000200016 .

NASCIMENTO, W.M. Condicionamento osmótico de sementes de hortaliças: potencialidades e implicações. Horticultura Brasileira, v.16, n.2, p.106-109, 1998. Available from: <http:/ /www.abhorticultura.com.br/biblioteca/arquivos/Download/ biblioteca/hb_16_2.pdf\#page=8>. Accessed: Sept. 09, 2010.

NASCIMENTO, W.M; ARAGÃO, F.A.S. Condicionamento osmótico de sementes de melão em relação ao vigor. Scientia Agricola, v.61, n.1, p.114-117, 2004. Available from: <http:/ /www.scielo.br/pdf/sa/v61n1/a19v61n1.pdf $>$. Accessed: Sept. 09, 2010. doi: 10.1590/S0103-90162004000100019.

POSSE, S.C.P. et al. Efeitos do condicionamento osmótico e da hidratação na geminação de sementes de pimentão (Capsicum annuum L.) submetidas à baixas temperaturas. Revista Brasileira de Sementes, v.23, n.1, p.123-127, 2002. Available from: <http://www.abrates.org.br/revista/artigos/2001/ v23n1/artigo17.pdf $>$. Accessed: Sept. 09, 2010.

SOUSA, D.M.G. et al. Fosfato nas pastagens. Cultivar Bovinos, v.13, 2p., 2004. Available from: <http:// www.grupocultivar.com.br/arquivos/bovinos13_fosfato.pdf $>$. Accessed: Sept. 09, 2010.

TAMBELINI, M.; PEREZ, S.C.J.G. Efeitos de estresse hídrico simulado com PEG (6000) ou manitol na germinação de sementes de barbatimão (Stryphnodendron polyphyllum Mart.). Revista Brasileira de Sementes, v.20, n.1, p.226-232, 1998.

TRIGO, M.F.O.O. et al. Efeitos do condicionamento osmótico com soluções aeradas de nitrato de potássio no desempenho de sementes de cebola. Revista Brasileira de Sementes, v.21, n.1, p.139-144, 1999. Available from: <http:// www.abrates.org.br/revista/artigos/1999/v21n1/artigo21.pdf $>$. Accessed: Sept. 09, 2010.

VILLELA, F.A. et al. Tabela de potencial osmótico em função da concentração de poletileno glicol 6000 e da temperatura. Pesquisa Agropecuária Brasileira, v.26, n.11-12, p.19571968, 1991. Available from: <http://webnotes.sct.embrapa.br/ pdf/pab1991/novdez/pab18_novdez_91.pdf>. 